Research Note

\title{
Mineral Nitrogen in a Crested Wheatgrass Stand: Implications for Suppression of Cheatgrass
}

\author{
Robert R. Blank ${ }^{1}$ and Tye Morgan ${ }^{2}$ \\ Authors are ${ }^{1}$ Soil Scientist and ${ }^{2}$ Research Technician, US Department of Agriculture-Agricultural Research Service, Great Basin Rangelands Research \\ Unit, Reno, NV 89512, USA.
}

\begin{abstract}
Cheatgrass (Bromus tectorum L.) is an exotic annual grass causing ecosystem degradation in western US rangelands. We investigated potential mechanisms by which crested wheatgrass (Agropyron cristatum L. Gaertn., Agropyron desertorum [Fisch. \{Ex Link\} Scult.]) suppresses the growth and invasibility of cheatgrass. Research focused on monthly mineral soil $\mathrm{N}$ availability and the proportional concentration of $\mathrm{NH}_{4}{ }^{+}-\mathrm{N}$ in a crested wheatgrass community by microsite (crested wheatgrass, unvegetated interspace, shrub subcanopy) and soil depth $(0-15,15-30 \mathrm{~cm})$ over a 1-yr period. Mineral soil $\mathrm{N}$ in crested wheatgrass microsites ranged from 0.24 to $1.66 \mathrm{mmol} \cdot \mathrm{kg}^{-1}$ and was not appreciably lower than the other microsites or other ecosystems we have measured in the Great Basin. The molar proportion of $\mathrm{NH}_{4}{ }^{+}-\mathrm{N}$ in the mineral $\mathrm{N}$ pool of crested wheatgrass averaged over $85 \%$ for the year and is significantly higher than the other microsites and far greater than other plant communities we have measured in the Great Basin. We conclude that crested wheatgrass does not suppress cheatgrass by controlling mineral $\mathrm{N}$ below a threshold level; rather, we hypothesize that it may limit nitrification and thereby reduce $\mathrm{NO}_{3}{ }^{-}-\mathrm{N}$ availability to the nitrophile cheatgrass.
\end{abstract}

\section{Resumen}

El pasto cheatgrass (Bromus tectorum L.) es un pasto exótico anual que está causando degradación en el ecosistema en los pastizales del oeste de los Estados Unidos. Investigamos los mecanismos potenciales por los cuales los pasto (Agropyron cristatum L. Gaertn. y Agropyron desertorum [Fisch. \{Ex Link\} Scult.]) suprimen el crecimiento y la habilidad de invasión del pasto cheatgrass. La investigación se enfocó en la disponibilidad mensual de nitrógeno mineral en el suelo (N), y la concentración proporcional de $\mathrm{NH}_{4}{ }^{+}-\mathrm{N}$ en una comunidad de A. cristatum L. Gaertn. por micro-sitios (A. cristatum L. Gaertn., inter-espacios sin vegetación y sub-dosel) con una profundidad del suelo de $(0-15,15-30 \mathrm{~cm})$ por un periodo de un año. El nitrógeno mineral del suelo en A. cristatum L. Gaertn. varían de 0.24 a $1.66 \mathrm{mmol} \cdot \mathrm{kg}^{-1}$ y no se aprecio más profundo que en los otros micro-sitios u otros ecosistemas que fueron medidos en la Great Basin. La proporción molar de $\mathrm{NH}_{4}{ }^{+}-\mathrm{N}$ en el concentrado de minerales de $\mathrm{N}$ de A. cristatum L. Gaertn. promedio arriba del $85 \%$ en el año y es significativamente mayor que los otros micro-sitios y bastante más grande que las otras comunidades de plantas que medimos en la Great Basin. Concluimos que el A. cristatum L. Gaertn. no suprime el pasto cheatgrass a través de controlar el nitrógeno abajo del nivel de tolerancia; en vez de eso, planteamos la hipótesis de que puede limitarse la nitrificación y por eso reducir la disponibilidad de $\mathrm{NO}_{3}{ }^{-}-\mathrm{N}$ para la nitro filiación del pasto cheatgrass.

Key Words: control, growth, nitrification, soil nitrogen

\section{INTRODUCTION}

In western US rangelands, over 300 introduced weeds have impacted native ecosystems (DiTomaso 2000). A portion of introduced weeds can become highly invasive and through "ecosystem engineering" can effect changes in soil physical and chemical properties (Chapin et al. 1997; Crooks 2002; Wright and Jones 2004). An invaded soil system may have altered nutrient cycling, nutrient availability, and microbial communities creating a positive feedback favoring the invasive species (Ehrenfeld 2003; Callaway et al. 2004).

Cheatgrass (Bromus tectorum L.) is the introduced weed with perhaps the largest ecological impact in western range-

Mention of a proprietary product does not constitute a guarantee or warranty of the product by USDA or the authors and does not imply its approval to the exclusion of the other products that also may be suitable.

Correspondence: Robert R. Blank, US Dept of Agriculture-Agricultural Research Service, 920 Valley Rd, Reno, NV 89512, USA. Email: bob.blank@ars.usda.gov

Manuscript received 30 August 2010; manuscript accepted 28 June 2011. lands (Knapp 1996). Its invasive success has been influenced by myriad factors including landscape disturbance, wide phenotypic plasticity, rapid growth rate, prolific seed production, and positive growth response to elevated atmospheric $\mathrm{CO}_{2}$ (Klemmedson and Smith 1964; Ziska et al. 2005; Chambers et al. 2007). Moreover, cheatgrass is nitrophilic-its growth and competitive ability is stimulated by elevated soil $\mathrm{N}$ availability (Kay and Evans 1965; Wilson et al. 1966; Vasquez et al. 2008a). Strategies to lower soil $\mathrm{N}$ availability can increase the competitive potential of slower growing native grasses, forbs, and shrubs (Lowe et al. 2003).

A successful rehabilitation strategy for weed-infested rangelands, at least in the short-term, has been to reduce available soil $\mathrm{N}$ by microbial immobilization of $\mathrm{N}$ via application of a labile $\mathrm{C}$ source (Reever Morghan and Seastedt 1999; Blumenthal et al. 2003). Alternatively, one can potentially reduce available soil $\mathrm{N}$ by planting species that control soil $\mathrm{N}$ levels to lower values (James et al. 2008). Crested wheatgrass (Agropyron desertorum, Agropyron cristatum) is an exotic perennial grass planted extensively in the west for forage, improving degraded range- 
lands, and erosion control (Rogler and Lorenz 1983; Young and Evans 1986). Established crested wheatgrass can suppress cheatgrass (Huber and Goodrich 1999), but no research has been undertaken to elucidate mechanisms. Our purpose is to report on the seasonal patterns of soil mineral $\mathrm{N}$ pools $\left(\mathrm{NO}_{3}{ }^{-}-\right.$ $\left.\mathrm{N}+\mathrm{NH}_{4}{ }^{+} \mathrm{N}\right)$ in a crested wheatgrass stand in northern Nevada, seeded in 1985. This stand has few cheatgrass plants, suggesting some form of suppression. Our initial working hypothesis posited that established crested wheatgrass reduces mineral soil $\mathrm{N}$ availability to a level below which cheatgrass is less competitive.

\section{METHODS}

We worked in a crested wheatgrass stand about $20 \mathrm{~km}$ north northwest of Reno, Nevada (lat $39^{\circ} 40^{\prime} 51^{\prime \prime} \mathrm{N}$; long $\left.119^{\circ} 55^{\prime} 36^{\prime \prime} \mathrm{W}\right)$ at an elevation of $1592 \mathrm{~m}$. Average annual precipitation is $28 \mathrm{~cm}$. The soil is Aquinas sandy loam, a fineloamy, mixed, superactive, mesic Haploxeralfic Argidurid, and developed in mixed granitic and volcanic colluvium. In 1985 following a wildfire, the area was seeded to cultivar Hycrest crested wheatgrass, a hybrid between $A$. cristatum and $A$. desertorum. In March 2009, a $100 \times 140 \mathrm{~m}$ site was established in a uniform area with similar slope and aspect. Site vegetation is dominated by Hycrest crested wheatgrass, with lesser amounts of the shrubs Morman tea (Ephedra nevadensis S. Wats.), desert peach (Prunus andersonii Gray), and big sagebrush (Artemisia tridentata ssp. wyomingensis Beetle and Young), the forbs hawksbeard (Crepis acuminata Nutt.), fiddleneck (Amsinckia tessellata A. Gray), and the grasses bluegrass (Poa secunda [J. Presl]), and squirreltail (Elymus elymoides [Raf. Swezey]). Cheatgrass is a minor component, but can assume dominance in areas in which crested wheatgrass did not establish or have died over time. A grid pattern was established and each month six different randomly selected grid intersections were chosen for sampling. At each of the six intersections, three microsites were sampled: center of the nearest crested wheatgrass, center of the nearest unvegetated interspace, and mid-subcanopy of the nearest shrub. Depths sampled were $0-15 \mathrm{~cm}$ (surface litter removed) and $15-30 \mathrm{~cm}$. Soil was sieved to remove $>2-\mathrm{mm}$ particles, homogenized and stored in plastic bags. A subsample was dried to $105^{\circ} \mathrm{C}$ for moisture content and to correct data to an oven dry basis. On fresh samples, we quantified $1.5 \mathrm{M} \mathrm{KCl}-$ extractable $\mathrm{N}$, which is a measure of mineral $\mathrm{N}$ readily available to plant roots (Bundy and Meisinger 1994). Extractions were done the same day as collection. Data were analyzed using a mixed-model analysis of variance, with repeated measures over soil depth. Fixed variables were time (12 mo) and depth $(0-15$, $15-30 \mathrm{~cm}$ ) with microsite (crested wheatgrass, interspace, shrub subcanopy) as the random variable. Total mineral $\mathrm{N}$ was $\log$ transformed to normalize.

\section{RESULTS}

Mineral soil $\mathrm{N}$ availability was influenced by significant $(P \leq 0.05)$ microsite $\times$ depth and depth $\times$ time interactions (Fig. 1). Overall, crested wheatgrass $\left(0.39 \mathrm{mmol} \cdot \mathrm{kg}^{-1}\right.$; $\mathrm{SE}=0.04)$ and shrub $\left(0.43 \mathrm{mmol} \cdot \mathrm{kg}^{-1} ; \mathrm{SE}=0.05\right)$ microsites had statistically greater mineral $\mathrm{N}$ than interspaces

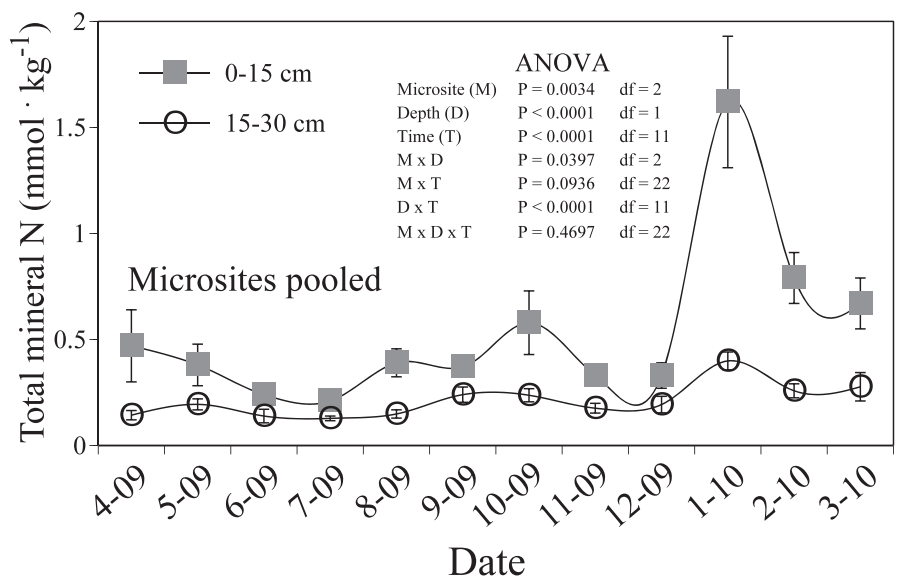

Figure 1. Graph showing significant microsite $\times$ time and depth $\times$ time interactions for mineral soil N. Bars are standard errors. Data fitted to spline interpolation.

$\left(0.29 \mathrm{mmol} \cdot \mathrm{kg}^{-1} ; \mathrm{SE}=0.03\right)$. Overall, mineral $\mathrm{N}$ was greater in the $0-15 \mathrm{~cm}$ depth $\left(0.53 \mathrm{mmol} \cdot \mathrm{kg}^{-1} ; \mathrm{SE}=0.04\right)$ than the $15-30 \mathrm{~cm}$ depth $\left(0.21 \mathrm{mmol} \cdot \mathrm{kg}^{-1} ; \mathrm{SE}=0.01\right)$, and its interaction with microsite occurred in the $0-15 \mathrm{~cm}$ depth where crested wheatgrass $\left(0.59 \mathrm{mmol} \cdot \mathrm{kg}^{-1} ; \mathrm{SE}=0.07\right)$ and shrub microsites $\left(0.61 \mathrm{mmol} \cdot \mathrm{kg}^{-1} ; \mathrm{SE}=0.09\right)$ were significantly greater than interspace microsites $\left(0.38 \mathrm{mmol} \cdot \mathrm{kg}^{-1}\right.$; $\mathrm{SE}=0.05)$. Mineral $\mathrm{N}$ was greatest during the winter months but largely controlled by the $0-15 \mathrm{~cm}$ depth increment. The depth $\times$ time interaction was due to significantly greater mineral $\mathrm{N}$ in the $0-15 \mathrm{~cm}$ depth increment on January 2010, February 2010, and March 2010.

The molar proportion of $\mathrm{NH}_{4}{ }^{+}-\mathrm{N}$ in the mineral $\mathrm{N}$ pool was affected by a significant $(P \leq 0.05)$ microsite $\times$ depth $\times$ time interaction (Fig. 2). Overall, crested wheatgrass microsites had a significantly greater proportion of $\mathrm{NH}_{4}{ }^{+}-\mathrm{N}(85 \% \mathrm{SE}=1.2)$ than the shrub $(72 \% \mathrm{SE}=2)$ and interspace $(75 \% \mathrm{SE}=1)$ microsites with dates of August 2009, September 2009, and November 2009 largely controlling the overall differences. All microsites had the greatest proportion of mineral $\mathrm{N}$ in the $\mathrm{NH}_{4}{ }^{+}$-N form in May 2009 (rapid plant growth) and during the winter. The three-way interaction occurred during August 2009 and September 2009, whence there were significant differences between shrub and interspace microsites for the $15-30 \mathrm{~cm}$ depth increment, but not the $0-15 \mathrm{~cm}$ increment.

\section{DISCUSSION}

Our working hypothesis asks if crested wheatgrass controls mineral soil $\mathrm{N}\left(\mathrm{NH}_{4}{ }^{+}-\mathrm{N}\right.$ and $\left.\mathrm{NO}_{3}{ }^{-}-\mathrm{N}\right)$ availability to levels below which cheatgrass is not as competitive. Low availability of soil $\mathrm{N}$ may allow native mid- and late-seral species to be successful against invasive annuals such as cheatgrass (Vasquez et al. 2008b). Unfortunately, we are unaware of any known threshold values of soil mineral $\mathrm{N}$ availability whence cheatgrass becomes less competitive. Insight into potential effects of measured mineral $\mathrm{N}$ levels in the crested wheatgrass stand can be accomplished by comparing among microsites. The average mineral soil $\mathrm{N}$ in the crested wheatgrass microsites, $0-15 \mathrm{~cm}$ depth, was $0.53 \mathrm{mmol} \cdot \mathrm{kg}^{-1}$ and not signi- 
ficantly different than the shrub microsites $\left(0.61 \mathrm{mmol} \cdot \mathrm{kg}^{-1}\right)$ but significantly greater than interspace microsites $(0.38 \mathrm{mmol}$. $\mathrm{kg}^{-1}$ ). Chen and Stark (2000) reported that soil beneath crested wheatgrass (15-yr-old stand) had greater $\mathrm{NO}_{3}{ }^{-}-\mathrm{N}$ than soil from interspaces or from sagebrush canopies. Furthermore, mineral $\mathrm{N}$ values measured in other communities, including sites occupied by cheatgrass (Table 1), are much lower than values measured beneath crested wheatgrass in this study. Microsite differences in mineral $\mathrm{N}$ availability are not unexpected because individual plant species regulate and constrain biochemical cycling (Cornwell et al. 2008). The yearly range of mineral soil $\mathrm{N}$ in the crested wheatgrass microsite, $0-15 \mathrm{~cm}$, varied from $0.24 \mathrm{mmol} \cdot \mathrm{kg}^{-1}$ in April 2009 to $1.66 \mathrm{mmol} \cdot \mathrm{kg}^{-1}$ in January 2010, which suggests some risk to invasion (Davis et al. 2000). Given these data, there is no compelling evidence that crested wheatgrass, at least at the particular site we chose, reduces mineral $\mathrm{N}$ availability below some threshold level and we, therefore, must reject our working hypothesis.

Our data suggests another possible mechanism, not originally hypothesized, by which established crested wheatgrass may suppress cheatgrass. Given the arid environment, we were quite surprised that for all dates, the molar proportion of $\mathrm{NH}_{4}{ }^{+}-\mathrm{N}$ in the mineral $\mathrm{N}$ pool beneath crested wheatgrass exceeded $65 \%$ and for 6 mo exceeded $90 \%$ and was statistically greater than the shrub and interspace microsites (Fig. 2). Moreover, the molar proportion of $\mathrm{NH}_{4}{ }^{+}-\mathrm{N}$ beneath crested wheatgrass greatly exceeds values obtained in other ecosystems in northern Nevada (Table 1). These data suggest that crested wheatgrass interacts with the soil to somehow reduce the rate of nitrification. Maintaining more mineral $\mathrm{N}$ in the $\mathrm{NH}_{4}{ }^{+}-\mathrm{N}$ form may decrease its availability to cheatgrass. Cheatgrass can utilize both $\mathrm{NH}_{4}{ }^{+}-\mathrm{N}$ and $\mathrm{NO}_{3}{ }^{-}-\mathrm{N}$, but has more rapid uptake kinetics for $\mathrm{NO}_{3}{ }^{-}-\mathrm{N}$ (Mackown et al. 2009). Moreover, in these arid environments with high temporal variability in soil water content, having a larger proportion of mineral $\mathrm{N}$ in the highly mobile $\mathrm{NO}_{3}{ }^{-}-\mathrm{N}$ form would increase the likelihood of transport to roots (Barber 1995). It also has been

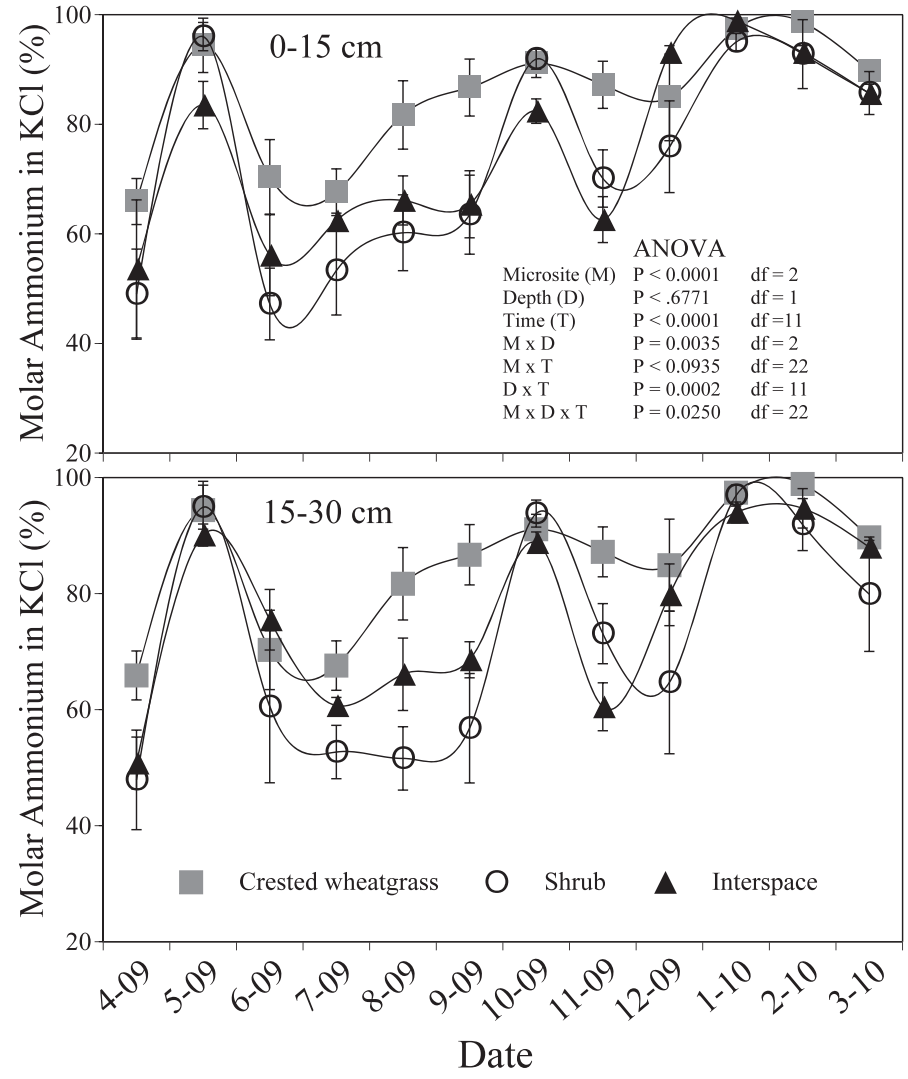

Figure 2. Graphs showing significant microsite $\times$ time interaction for molar \% of $\mathrm{NH}_{4}^{+}-\mathrm{N}$ in mineral soil $\mathrm{N}$. Bars are standard errors. Data fitted to spline interpolation.

shown that cheatgrass can elevate soil nitrification rates (Norton et al. 2008). We propose that a potentially fruitful research area in the invasion ecology of cheatgrass is to test a hypothesis that plant communities, which poise the proportion of $\mathrm{NH}_{4}{ }^{+}-\mathrm{N}$ in the mineral pool at high levels, may be resistant to cheatgrass

Table 1. Mineral soil $\mathrm{N}$ and molar proportion of $\mathrm{NH}_{4}{ }^{+} \mathrm{N}$ in the mineral pool for several plant communities in Nevada.

\begin{tabular}{|c|c|c|c|c|c|c|c|c|}
\hline Location & Date & Community $^{1}$ & Microsite & No. samples & Parent material & Depth & Mineral N N & Mole $\mathrm{NH}_{4}{ }^{+}-\mathrm{N}$ \\
\hline & & & & & & $\mathrm{cm}$ & $\mathrm{mmol} \cdot \mathrm{kg}^{-1}$ & $\%$ \\
\hline Lat $41^{\circ} 13^{\prime} 40^{\prime \prime} \mathrm{N}$, long & December 2001 & Intact sagebrush & Shrub interspace & 4 & Loess & $0-5$ & $0.63(0.11)$ & $11.1(3.3)$ \\
\hline \multirow[t]{5}{*}{$117^{\circ} 24^{\prime} 14^{\prime \prime} \mathrm{W}$} & December 2001 & Intact sagebrush & Shrub interspace & 4 & Loess & $5-15$ & $0.16(0.03)$ & $13.0(3.2)$ \\
\hline & December 2001 & Intact sagebrush & Sagebrush subcanopy & 4 & Loess & $0-5$ & $0.76(0.29)$ & $14.9(1.8)$ \\
\hline & December 2001 & Intact sagebrush & Sagebrush subcanopy & 4 & Loess & $5-15$ & $0.12(0.01)$ & $12.3(4.1)$ \\
\hline & December 2001 & Burned sagebrush & Cheatgrass & 4 & Loess & $0-5$ & $0.52(0.14)$ & $10.9(4.9)$ \\
\hline & December 2001 & Burned sagebrush & Cheatgrass & 4 & Loess & $5-15$ & $0.25(0.08)$ & $14.1(2.3)$ \\
\hline Lat $39^{\circ} 09^{\prime} 33^{\prime \prime} \mathrm{N}$, long & May 2002 & Pinyon-Juniper & Interspace & 4 & Welded Tuff & $0-3$ & $1.67(0.23)$ & $51.3(6.2)$ \\
\hline \multirow[t]{5}{*}{$117^{\circ} 23^{\prime} 33^{\prime \prime} \mathrm{W}$} & May 2002 & Pinyon-Juniper & Interspace & 4 & Welded Tuff & $3-8$ & $0.92(0.11)$ & $41.6(7.4)$ \\
\hline & May 2002 & Pinyon-Juniper & Sagebrush subcanopy & 4 & Welded Tuff & $0-3$ & $1.82(0.26)$ & $28.1(2.7)$ \\
\hline & May 2002 & Pinyon-Juniper & Sagebrush subcanopy & 4 & Welded Tuff & $3-8$ & $0.82(0.04)$ & $30.3(4.1)$ \\
\hline & May 2002 & Pinyon-Juniper & Juniper understory & 4 & Welded Tuff & $0-3$ & $1.02(0.34)$ & $43.8(2.8)$ \\
\hline & May 2002 & Pinyon-Juniper & Juniper understory & 4 & Welded Tuff & $3-8$ & $0.41(0.08)$ & $44.2(0.8)$ \\
\hline Lat $40^{\circ} 08^{\prime} 14^{\prime \prime} \mathrm{N}$, long & April 1998-May 2010 & Invaded winterfat & Cheatgrass & 241 & Eolian sand & $0-20$ & $0.21(0.02)$ & $32.3(1.9)$ \\
\hline $120^{\circ} 04^{\prime} 38^{\prime \prime} \mathrm{W}$ & April 1998-May 2010 & Invaded winterfat & Winterfat & 83 & over lacustrine & $0-20$ & $0.15(0.02)$ & $23.6(2.8)$ \\
\hline
\end{tabular}

${ }^{1}$ Data from studies undertaken by Agricultural Research Service, Reno, soils lab using similar analytical proctocols to the present study. Standard errors are in parentheses. 
invasion. In California, exotic grasses greatly increased nitrification rates (Hawkes et al. 2005).

\section{MANAGEMENT IMPLICATIONS}

Understanding mechanisms by which perennial grasses suppress invasive annual grasses would aide in revegetation efforts. Crested wheatgrass does not appear to suppress cheatgrass by reducing mineral soil $\mathrm{N}$ below a threshold level. Rather, our data suggest that crested wheatgrass may inhibit cheatgrass expansion by limiting the rate of soil nitrification, thus causing the mineral $\mathrm{N}$ fraction to have a high proportion of $\mathrm{NH}_{4}{ }^{+} \mathrm{N}$. We propose, as a hypothesis for testing, that native perennial communities also reduce nitrification. Nitrapyrin, a synthetic nitrification inhibitor, has been shown to decrease plant density and herbage of the annual grass medusahead and the density and cover of cheatgrass relative to controls (Young et al. 1997, 1998). The use of chemical nitrification inhibitors to control cheatgrass should be researched.

\section{LITERATURE CITED}

BARBeR, S. 1995. Soil nutrient bioavailability: a mechanistic approach. New York, NY, USA: John Wiley \& Sons. $384 \mathrm{p}$.

Blumenthal, D. M., N. R. Jordan, and M. P. Russelle. 2003. Soil carbon addition controls weeds and facilitates prairie restoration. Ecological Applications 13:605-615.

Bundy, L. C., And J. J. Meisinger. 1994. Nitrogen availability indices. In: R. W. Weaver, S. Angle, P. Bottomley, D. Bezdicek, S. Smith, A. Tabatabai, and A. Wollum [EDS.]. Methods of soil analysis. Part 2. Microbiological and biochemical properties. Madison, WI, USA: Soil Science Society of America. p. 951-984.

Callaway, R. M., G. C. Thelen, A. Rodriguez, and W. E. Holben. 2004. Soil biota and exotic plant invasion. Nature 427:731-733.

Chambers, J. C., B. A. Roundy, R. R. Blank, S. E. Meyer, and A. Whittaker. 2007. What makes Great Basin sagebrush ecosystems invasible by Bromus tectorum? Ecological Monographs 77:117-145.

Chapin, F. S., III, B. H. Walker, R. J. Hobbs, D. U. Hooper, J. H. Lawton, O. E. Sala, AND D. TILMAN. 1997. Biotic control over the functioning of ecosystems. Science 277:500-504.

Chen, J., AND J. M. StaRk. 2000. Plant species effects and carbon and nitrogen cycling in a sagebrush-crested wheatgrass soil. Soil Biology and Biochemistry $32: 47-57$.

Cornwell, W. K., J. H. C. Cornelissen, K. Amatangelo, E. Dorrepaal, V. T. Eviner, 0. Godoy, S. E. Hobbie, B. Hoorens, H. Kurokawa, N. Pérez-Harguindeguy, H. M. Quested, L. S. Santiago, D. A. Wardle, I. J. Wright, R. Aerts, S. D. Allison, P. Van Bodegom, V. Brovkin, A. Chatain, T. V. Callaghan, S. Díaz, E. Garnier, D. E. Gurvich, E. Kazakou, J. A. Klein, J. Read, P. B. Reich, N. A. Soudzilovskaia, M. Victoria Vaieretti, and M. Westoby. 2008. Plant species traits are the predominant control on litter decomposition rates within biomes worldwide. Ecology Letters 11:1065-1071.

Crooks, J. A. 2002. Characterizing ecosystem-level consequences of biological invasions: the role of ecosystem engineers. Oikos 97:153-166.

Davis, M. A., J. P. Grime, and K. Thompson. 2000. Fluctuating resources in plant communities: a general theory of invasibility. Journal of Ecology 88:528-534.

DiTomaso, J. M. 2000. Invasive weeds in rangelands: species, impacts, and management. Weed Science 48:255-265.
Ehrenfeld, J. G. 2003. Effects of exotic plant invasions on soil nutrient cycling processes. Ecosystems 6:503-523.

Hawkes, C. V., I. F. Wren, D. J. Herman, and M. K. Firestone. 2005. Plant invasion alters nitrogen cycling by modifying the soil nitrifying community. Ecology Letters 8:976-985.

Huber, A., AND S. GoodRICH. 1999. Big sagebrush, crested wheatgrass, and grazing on gravel-cobble pediments of the Duchesne River Formation and Quaternary deposits in Uintah County, Utah. In: E. D. McArthur, W. K. Ostler, and C. L. Wambolt [comps.]. Proceedings: Shrubland Ecotones; 12-14 August 1998; Ephraim, UT, USA. Ogden, UT, USA: US Department of Agriculture, Forest Service, Rocky Mountain Research Station. USDA Forest Service Proceedings RMRS-P-11. p. 181-185.

James, J. J., K. W. Davies, R. L. Sheley, and Z. T. Aanderud. 2008. Linking nitrogen partitioning and species abundance to invasion resistance in the Great Basin. Oecologia 156:637-648

Kay, B. L., And R. A. Evans. 1965. Effects of fertilization on a mixed stand of cheatgrass and intermediate wheatgrass. Journal of Range Management 18:7-11.

KLemmedson, J. O., AND J. G. Smith. 1964. Cheatgrass (Bromus tectorum L.). The Botanical Review 30:226-262.

KnapP, P. A. 1996. Cheatgrass (Bromus tectorum L.) dominance in the Great Basin desert: history, persistence, and influences to human activities. Global Environmental Change 6:31-52.

Lowe, P., W. K. Lauenroth, and I. C. Burke. 2003. Effects of nitrogen availability on competition between Bromus tectorum and Bouteloua gracilis. Plant Ecology 167:247-254.

MacKown, C. T., T. A. Jones, D. A. Johnson, T. A. Monaco, and M. G. Redinbaugh. 2009. Nitrogen uptake by perennial and invasive annual grass seedlings: nitrogen form effects. Soil Science Society of America Journal 73:1864-1870.

Norton, U., A. R. Mosier, J. A. Morgan, J. D. Derner, L. J. Ingram, and P. D. Stahl. 2008. Moisture pulses, trace gas emissions and soil $\mathrm{C}$ and $\mathrm{N}$ in cheatgrass and native grass-dominated sagebrush-steppe in Wyoming, USA. Soil Biology and Biochemistry 40:1421-1431.

Reever Morghan, K. T., and T. R. Seastedt. 1999. Effects of soil nitrogen reduction on nonnative plants in restored grasslands. Restoration Ecology 7:51-55.

Rogler, G. A., And R. J. LoRenz. 1983. Crested wheatgrass: early history in the United States. Journal of Range Management 36:91-93.

Vasquez, E., R. Sheley, and T. Svejcar. 2008a. Nitrogen enhances the competitive ability of cheatgrass (Bromus tectorum) relative to native grasses. Invasive Plant Science and Management 1:287-295.

Vasquez, E., R. Sheley, and T. Svejcar. 2008b. Creating invasion resistant soils via nitrogen management. Invasive Plant Science and Management 1:304-314.

Wilson, A. M., G. A. HarRIS, and D. H. Gates. 1966. Fertilization of mixed cheatgrass-bluebunch wheatgrass stands. Journal of Range Management 19:134-137

Wright, J. P., and C. G. Jones. 2004. Predicting effects of ecosystem engineers on patch-scale species richness from primary productivity. Ecology 85:2071-2081.

Young, J. A., C. D. Clements, and R. R. Blank. 1997. Influence of nitrogen on antelope bitterbrush seedling establishment. Journal of Range Management $50: 536-540$

Young, J. A., And R. A. Evans. 1986. History of crested wheatgrass in the intermountain area. In: K. L. Johnson [ED.]. Crested wheatgrass: its values, problems and myths. Symposium Proceedings. Logan UT, USA: Utah State University. p. 21-26.

Young, J. A., J. D. Trent, R. R. Blank, and D. E. Palmquist. 1998. Nitrogen interactions with medusahead (Taeniatherum caput-medusae ssp. asperum) seedbanks. Weed Science 46:191-195.

ZISKA, L. H., J. B. ReEves III, AND B. Blank. 2005. The impact of recent increases in atmospheric $\mathrm{CO}_{2}$ on biomass production and vegetative retention of cheatgrass (Bromus tectorum): implications for fire disturbance. Global Change Biology 11:1325-1332. 